\begin{tabular}{c} 
Efficient Vol 1 (3) (2018): 242-251 DOI: https://doi.org/10.15294/efficient.vii3.27869 \\
$\begin{array}{c}\text { Indonesian Journal of Development Economics } \\
\text { http: journal.unnes.ac.id/sju/index.php/efficient }\end{array}$ \\
\hline
\end{tabular}

\title{
Determinan Keputusan Melakukan Migrasi Ulang-Alik
}

\author{
Rifqi Nur Fahmy \\ Jurusan Ekonomi Pembangunan,Fakultas Ekonomi, Universitas Negeri Semarang
}

Permalink/DOI: https://doi.org/10.15294/efficient.viiz.27869

\begin{abstract}
The aim of this research is to analyze the influence of dependent variable of family dependent, education level, age, marital status, and distance partially to workforce's decision to migrate from Surakarta to Karanganyar Regency. This research used binary logistic regression analysis method. The sample in this research is 100 respondents.

The result of binary logistic regression model analysis in this research shows that from five independent variables, there are two variables that have significant effect on workforce's decision to do the commuter migration that is dependent variable of family and marital status. While the variable level of education, age, and distance have no effect on workforce's decisions to do the commuter migration.
\end{abstract}

Keywords: Commuter Migration, Decision, Binnary Logistic Regression, Workforce.

\begin{abstract}
Abstrak
Tujuan dari penelitian ini adalah untuk menganalisis pengaruh variabel dependen dependen keluarga, tingkat pendidikan, usia, status perkawinan, dan jarak secara parsial terhadap keputusan tenaga kerja untuk bermigrasi dari Surakarta ke Kabupaten Karanganyar. Penelitian ini menggunakan metode analisis regresi logistik biner. Sampel dalam penelitian ini adalah 100 responden.

Hasil analisis model regresi logistik biner dalam penelitian ini menunjukkan bahwa dari lima variabel independen, ada dua variabel yang berpengaruh signifikan terhadap keputusan angkatan kerja untuk melakukan migrasi komuter yang merupakan variabel dependen keluarga dan status perkawinan. Sedangkan tingkat variabel pendidikan, usia, dan jarak tidak berpengaruh pada keputusan tenaga kerja untuk melakukan migrasi komuter.
\end{abstract}

Kata Kunci: Migrasi Komuter, Keputusan, Regresi Binnary Logistic, tenaga kerja

How to Cite: Fahmy, R. (2018). Determinan Keputusan Melakukan Migrasi Ulang-Alik. EFFICIENT Indonesian Journal of Development Economics, 1(3), 242-251. https://doi.org/10.15294/efficient.vii3.27869

(C) 2018 Semarang State University. All rights reserved

\begin{tabular}{ll}
\hline Alamat Korespondensi : & ISSN \\
Alamat: Gedung L2 Lantai 2 FE Unnes & \\
Kampus Sekaran, Gunungpati, Semarang, 50229 & \\
E-mail : efficientjournal@gmail.com &
\end{tabular}




\section{PENDAHULUAN}

Mobilitas penduduk dapat dikatakan sebagai salah satu fenomena yang menjadi aspek dalam perkembangan pertumbuhan penduduk. Mobilitas penduduk juga merupakan suatu kegiatan yang dapat meningkatkan kehidupan yang lebih baik atau layak bagi penduduk dari daerah asal yang tingkat pendapatannya lebih rendah dibandingkan dengan pendapatan yang ada di daerah tujuan.

Potensi mobilitas penduduk juga diartikan sebagai suatu cara atau bentuk perpindahan penduduk untuk mencari pekerjaan dengan memanfaatkan peluang kerja yang ada di daerah tujuan. Inilah yang menyebabkan masih banyaknya penduduk usia kerja yang melakukan mobilitas ke daerah tujuan. Migrasi yang dilakukan oleh tenaga kerja dapat dilakukan secara internal atau dalam negeri maupun secara internasional atau lintas negara. Niat individu untuk bermigrasi berbeda-beda, dan dipengaruhi oleh masing-masing individu itu sendiri yang melakukan migasi. Menurut Everett S. Lee menyatakan bahwa terdapat empat faktor pedorong yang menyebabkan seseorang untuk melakukan keputusan bermigrasi. Faktor-faktor tersebut adalah faktor yang ada di daerah asal seperti pendapatan di daerah asal yang rendah, terbatasnya lapangan pekerjaan di daerah asal. Faktor yang ada di daerah tujuan seperrti pendapatan yang lebih /tinggi, lapangan pekerjaan yang dapat menyerap tenaga kerja atau lapangan pekerjaan sesuai bidang/ketrampilan yang dimiliki tenaga kerja. Rintangan yang menghambat seperti jarak dari daerah asal ke daerah tujuan, sarana prasarana yang ada untuk melakukan migrasi. Faktor-faktor individu seperti beban tanggungan keluarga. Faktor pendorong dan faktor penarik menurut Everett S. Lee dapat dijelaskan bahwa rendahnya penyerapan tenaga kerja di daerah asal mendorong penduduk untuk mencari dan memanfaatkan kesempatan kerja yang ada di daerah tujuan untuk bermigrasi. Tingkat pendapatan yang ditawarkan di daerah tujuan relatif lebih baik dibandingkan dengan tingkat pendapatan yang ada di daerah asal. Menurut E.G. Ravenstein (1985) berpendapat bahwa migrasi dengan jarak yang dekat dan migrasi dengan jarak jauh lebih tertuju ke pusatpusat perdagangan dan industri. Perbedaan antara daerah asal dan daerah tujuan mengakibatkan tenaga kerja melakukan migrasi. Karena dengan biaya yang dibutuhkan untuk mencukupi kebutuhan keluarga, maka motif ekonomi merupakan dorongan utama seseorang untuk melakukan migrasi.

Dilihat secara umum bahwa jumlah pencari kerja di Kota Surakarta pada tahun 2015 sebanyak 284.076 orang, dan setiap tahunnya dari tahun 2011 sampai 2015 jumlah angkatan kerja yang sudah bekerja selalu mengalami peningkatan. Dilihat menurut pendidikan tertinggi yang ditamatkan jumlah angkatan kerja yang sudah bekerja paling banyak jumlah tenaga kerja yang ditamatkan dari Sekolah Menengah Kejuruan, hal tersebut mengakibatkan tenaga kerja yang sudah mempunyai keahlian sesuai dengan kejuruan yang dimiliki setelah lulus akan mencari pekerjaan sesuai dengan kejuruan/keahlian yang dimiliki tenaga kerja. Dalam bermobilitas, penduduk Kota Surakarta lebih tertarik melakukan migrasi ulang-alik dengan jarak yang dekat. Jarak yang dekat antara Kota 
Surakarta dengan Kabupaten Karanganyar mendorong tenaga kerja untuk melakukan migrasi, akan tetapi selain faktor jarak, karena faktor lapangan pekerjaan yang tidak sesuai dengan ketrampilan juga mengakibatkan tenaga kerja melakuka migrasi. Dilihat secara umum bahwa jumlah penduduk yang bekerja menurut kelompok umur dan jenis kelamin di Kota Surakarta pada tahun 2015 sebanyak 271.199 orang, setiap kelompok umur mengalami kenaikan dan penurunan jumlah usia yang bekerja, dan jumlah paling banyak berada di kelompok umur 35 sampai 44 tahun yaitu sebesar 61.429 tenaga kerja.

Akan tetapi, semakin tua umur tenaga kerja dari umur 55 tahun sampai 65 ke atas mengalami penurunan, karena semakin tua umur tenaga kerja biasanya rentan melakukan migrasi ulang-alik. Perbedaan Upah Minimun Kota/Kabupaten (UMK) juga menjadi acuan dasar tenaga kerja yang melakukan migrasi ulang-alik. Mereka pasti lebih memiih bermigrasi ke daerah tujuan yang memiliki UMK lebih tinggi dibandingkan daerah asal tenaga kerja.

Tabel 1. Perbandingan UMK di SUBOSUKOWONOSRATEN Tahun 2016

\begin{tabular}{ll}
\hline Kabupaten/Kota & $\begin{array}{l}\text { UMK Tahun } \\
2016\end{array}$ \\
\hline Kabupaten Boyolali & Rp. 1.403.500,- \\
Kabupaten Klaten & Rp. 1.400.00o,- \\
Kabupaten Sukoharjo & Rp. 1.396.00o,- \\
Kabupaten Wonogiri & Rp. 1.293.000,- \\
Kabupaten Karanganyar & Rp. 1.420.000,- \\
Kabupaten Sragen & Rp. 1.300.000,- \\
Kota Surakarta & Rp. 1.418.000,- \\
\hline Sumber : Keputusan & Gubernur Jawa \\
Tengah Nomor 560/66 & Tahun 2015
\end{tabular}

Berdasarkan tabel 1 dapat dilihat bahwa perbandingan UMK di Subosukowonosraten menunjukan bahwa UMK Kabupaten Karanganyar merupakan UMK yang paling tinggi diantara kabupaten lainnya, berarti hal tersebut menunjukan bahwa UMK Kabupaten Karanganyar lebih tinggi dibandingkan Kota Surakarta. Hal tersebut juga menjadi pertimbangan para migran untuk bermigrasi ke daerah tujuan yang memiliki UMK lebih tinggi dibandingkan daerah asal. Dengan pendapatan yang lebih tinggi dibandingkan daerah asal akan lebih memilih melakukan migrasi supaya dapat mencukupi kebutuhan hidup tenaga kerja.

Melalui penelitian ini ingin mengungkapkan beberapa fenomena sosial yang dapat disimpulkan dari data yang diamati terkait beberapa pertimbangan tenaga kerja untuk memilih melakukan migrasi ulang-alik atau memilih tetap tinggal di daerah asal akan tetapi, mereka lebih memilih untuk bekerja di luar daerah atau daerah tujuan migrasi ulang-alik untuk mencari pekerjaan yang sesuai dengan skill atau kemampuan dan mencari lapangan pekerjaan yang lebih banyak dibandingkan dengan pekerjaan yang ada di daerah asal. Dari uraian penjelasan di atas peneliti ingin melakukan penelitian dengan judul "Determinan Keputusan Melakukan Migrasi Ulang-Alik (Studi Kasus Tenaga Kerja Asal Kota Surakarta Ke Kabupaten Karanganyar)”

\section{METODE PENELITIAN}

Variabel dependen pada penelitian ini adalah warga Kota Surakarta yang mempunyai pekerjaan di Kabupaten Karanganyar. $\mathrm{D}=1$ jika melakukan migrasi ulang-alik, $\mathrm{D}=\mathrm{o}$ jika lainnya. Variable independen dalam penelitian ini adalah 
Beban tanggungan keluarga yang ditinggal yang berada dalam satu rumah. Tingkat pendidikan ini diukur berdasarkan skor (scoring), o = Tidak/Belum Tamat SD, $1=$ Tamat SD, 2 = Tamat SMP, 3 = Tamat SMA, dan $4=$ Tamat Diploma/Sarjana. Usia merupakan variabel yang diukur melalui satuan tahun. Status pernikahan dalam penelitian ini $\mathrm{D}=1$ jika menikah, $\mathrm{D}=\mathrm{o}$ jika lainnya (belum menikah atau duda/ janda). Jarak diukur melalui satuan kilometer. Jenis data yang akan digunakan dalam penelitian ini adalah data primer ini diperoleh dengan melakukan survei langsung ke daerah penelitian dan melakukan pengisian kuisioner berdasarkan kuesioner yang telah disusun terhadap responden yang memenuhi syarat.

Populasi penelitian ini adalah tenaga kerja yang berasal dari Kota Surakarta, menetap tinggal di Kota Surakarta. Pengambilan sampel pada penelitian ini menggunakan teknik non probability sampling, dan untuk menentukan besarnya sampel menggunakan rumus Slovin. Dari hasil perhitungan menggunakan rumus slovin sampel yang dihasilkan adalah 99,99 maka dibulatkan menjadi 100 responden.

Data yang dikumpulkan dalam penelitian dan diolah, kemudian dianalisis dengan alat statistik menggunakan regresi logistik (Logistic Regression Model) dimana variabel terikatnya berbentuk non parametris atau kategoris. Kategorisasi variabel terikat dapat dijelaskan angka 1 untuk responden yang melakukan migrasi ulang-alik, dan angka o untuk responden yang tidak atau lainnya melakuan migrasi ulang-alik. Dalam penelitian ini dapat disusun model persamaan fungsi sebagai berikut:

$$
\mathrm{Y}=\mathrm{f}\left(\mathrm{X}_{1}+\mathrm{X}_{2}+\mathrm{X}_{3}+\mathrm{X}_{4}+\mathrm{X}_{5}\right)
$$

Adapun bentuk model ekonometrikanya dapat dituliskan sebagai berikut:

$$
\begin{aligned}
\mathrm{Y} & =\beta_{\mathrm{o}}+\beta_{1} \text { Beban }+\beta_{2} \text { Pendidikan }+\beta_{3} \text { Usia } \\
& +\beta_{4} \text { Status }+\beta_{5} \text { Jarak }+\mu \cdots \ldots \ldots \ldots \ldots \ldots \ldots \ldots \ldots . . . \cdots
\end{aligned}
$$

\begin{tabular}{|c|c|}
\hline $\mathrm{Y}$ & $\begin{array}{l}\text { keputusan melakukan migrasi } \\
\text { ulang alik }\end{array}$ \\
\hline Beban & beban tanggungan keluarga \\
\hline Pendidikan & tingkat pendidikan \\
\hline Usia & Usia \\
\hline Status & status pernikahan \\
\hline Jarak & Jarak \\
\hline$\beta_{\mathrm{o}}$ & Intersep \\
\hline$\beta_{1,2,3,4,5}$ & koefisien regresi \\
\hline M & $\begin{array}{l}\text { error terms } \\
\text { pengganggu) }\end{array}$ \\
\hline
\end{tabular}

Dimana:

\section{HASIL DAN PEMBAHASAN}

Berdasarkan Beban Tanggungan Keluarga Profil responden menurut beban tanggungan keluarga, diketahui bahwa sebagian besar responden mempunyai jumlah beban tanggungan keluarga 3 orang yaitu sebesar 31 persen, kemudian responden yang mempunyai jumlah beban tanggungan keluarga 6 orang dan 8 orang yaitu sebesar o persen. Selanjutnya responden yang mempunyai jumlah beban tanggungan keluarga 7 orang dan 9 orang yaitu sebesar 1 persen. Berdasarkan Tingkat Pendidikan Terakhir Jumlah responden menurut tingkat pendidikan terakhir, diketahui pendidikan terakhir responden jumlah responden 
tertinggi pada pendidikan terakhir tamat SMA/Sederajat sebesar 70 persen. Sedangkan untuk pendidikan terakhir responden jumlah pada pendidikan terakhir tidak/belum tamat SD/Sederajat sebesar 2 persen. Berdasarkan Usia Jumlah responden menurut usia dapat diketahui bahwa sebagian besar responden pada rentang usia 26 - 30 tahun dan $41-45$ tahunyaitu sebesar 19 persen. Sedangkan responden pada rentang usia tertinggi $61-65$ tahun yaitu sebesar 1 persen.

Berdasarkan Status Pernikahan Profil responden menurut status pernikahan, diketahui bahwa jumlah responden berstatus menikah lebih banyak yaitu 77 persen dari total responden. Sedangkan responden berstatus lainnya sebesar 23 persen. Sebagian besar dalam status menikah, karena hal tersebut menjadi motivasi keinginan untuk mendapatkan pendapatan yang lebih tinggi demi mencukupi kebutuhan keluarga.

Berdasarkan jarak responden terbanyak berada pada rentang jarak antara 6 - $10 \mathrm{~km}$, yaitu 49 persen. Hal ini sangat dimungkinkan dengan jarak dari tempat tinggal ke tempat bekerja tidak jauh sehngga mendorong responden untuk melakukan migrasi ulang - alik. Sedangkan jumlah responden yang terkecil pada rentang jarak $21-25 \mathrm{~km}$, yaitu 3 persen.

Berdasarkan Alasan Tidak Mencari Pekerjaan Di Daerah Asal Responden terbanyak berada pada alasan tidak sesuai dengan keahlian yang dimiliki, dan alasan lainnya, yaitu 30 persen. Terdapat berbagai alasan lainnya dari jawaban responden yaitu karena sedapatnya pekerjaan, ajakan keluarga/teman, pekerjaan yang cocok, kesejahteraannya lebih baik, penempatan dari atasan, sudah melamar pekerjaan di daerah asal tetapi tidak mendapat tanggapan. Sedangkan jumlah responden yang terkecil responden terendah pada alasan lahan garapan sedikit, yaitu 4 persen. Selain pendapatan yang tinggi yang mendorong tenaga kerja untuk melakukan migrasi, hal tersebut menunjukan bahwa responden akan mencari pekerjaan sesuai dengan keahlian yang tenaga kerja atau responden miliki, sehingga alasan kenapa tidak memilih pekerjaan di daerah asal paling tinggi persentasenya adalah tidak sesuai dengan keahlian yang dimiliki responden.

Berdasarkan Yang Menjadi Tulang Punggung Keluarga Profil responden menurut yang menjadi tulang punggung keluarga, diketahui bahwa jumlah responden yang menjadi tulang punggung keluarga lebih banyak yaitu 54 persen dari total responden.Sedangkan responden yang bukan menjadi tulang punggung keluarga sebesar 46 persen.

\section{Hasil Analisis Binary Logistic Regression}

Terdapat 100 responden yang dipilih untuk mewakili perilaku tenaga kerja yang melakukan migrasi ulang-alik tenaga kerja asal Kota Surakarta ke Kabupaten Karanganyar. Untuk membuktikan hipotesis penelitian, peneliti menggunakan Biinary Logistic Regression.

Berdasarkan dari hasil analisis maka dapat dirumuskan model ekonometrika adalah sebagai berikut :

$$
\begin{aligned}
\mathrm{Y}= & \beta_{\mathrm{o}}+\beta_{1} \text { Beban }+\beta_{2} \text { Pendidikan }+\beta_{3} \text { Usia } \\
& +\beta_{4} \text { Status }+\beta_{5} \text { Jarak }+\mu \ldots \ldots \ldots \ldots \ldots \ldots \ldots \ldots \ldots \ldots \ldots \ldots
\end{aligned}
$$

Keputusan migrasi $=-4,926+2,228$ beban $+1,763$ pendidikan $+0,025$ usia + 3,799 status $-0,270$ jarak $+\mu$ (error) 


\begin{tabular}{|c|c|c|c|}
\hline S.E. $=$ & 3,804 & 0,902 & 0,905 \\
\hline & 0,046 & 1,778 & 0,243 \\
\hline Sig. $=$ & $\begin{array}{l}(0,195) \\
(0,596)\end{array}$ & $\begin{array}{l}(0,014) \\
(0,033)\end{array}$ & $(0,051)$ \\
\hline
\end{tabular}

Berdasarkan hasil pengolahan data maka dapat dinyatakan bahwa hasil uji Z pada tingkat kesalahan $5 \%$ untuk beban tanggungan keluarga menunjukkan bahwa z hitung adalah sebesar 6,101 dan probabilitas $\mathrm{z}$ hitung sebesar o,o014 lebih kecil dari $\alpha$ (o,05), sehingga Ha dapat terima. Hal ini berarti bahwa beban tanggungan keluarga secara parsial berpengaruh secara signifikan terhadap keputusan tenaga kerja melakukan migrasi ulang-alik. Dengan nilai koefisien sebesar 2,228, angka ini menunjukkan bahwa apabila terdapat kenaikan beban tanggungan keluarga sebesar 1 satuan indeks maka akan menyebabkan kenaikan keputusan tenaga kerja melakukan migrasi komutasi sebesar 2,228\%. Sebaliknya, apabila terdapat penurunan beban tanggungan keluarga sebesar satuan indeks maka akan menyebabkan penurunan keputusan tenaga kerja melakukan migrasi ulang alik sebesar 2,228\%. Hasil uji Z pada tingkat kesalahan $5 \%$ untuk tingkat pendidikan menunjukkan bahwa $\mathrm{z}$ hitung adalah sebesar 3,797 dan probabilitas $\mathrm{z}$ hitung sebesar 0,051 lebih besar dari $\alpha$ (o,05), sehingga Ho dapat terima. Hal ini berarti bahwa tingkat pendidikan secara parsial tidak berpengaruh secara signifikan terhadap keputusan tenaga kerja melakukan migrasi ulang-alik. Hasil uji Z pada tingkat kesalahan $5 \%$ untuk usia menunjukkan bahwa $\mathrm{z}$ hitung adalah sebesar 0,281 dan probabilitas z hitung sebesar o,0596 lebih besar dari $\alpha(0,05)$, sehingga Ho dapat terima. Hal ini berarti bahwa usia secara parsial tidak berpengaruh secara signifikan terhadap keputusan tenaga kerja melakukan migrasi ulang-alik. Hasil uji $\mathrm{Z}$ pada tingkat kesalahan $5 \%$ untuk status pernikahan menunjukkan

\section{Uji Wald/Uji Z-Statistik}

bahwa z hitung adalah sebesar 4,568 dan probabilitas z hitung sebesar 0,033 lebih kecil dari $\alpha(0,05)$, sehingga Ha dapat terima. Hal ini berarti bahwa status pernikahan secara parsial berpengaruh secara signifikan terhadap keputusan tenaga kerja melakukan migrasi ulang-alik. Dengan nilai koefisien sebesar 3,799, angka ini menunjukkan bahwa apabila terdapat kenaikan status pernikahan sebesar 1 satuan indeks maka akan menyebabkan kenaikan keputusan tenaga kerja melakukan migrasi ulang-alik sebesar 3,799\%. Sebaliknya, apabila terdapat penurunan status pernikahan sebesar satuan indeks maka akan menyebabkan penurunan keputusan tenaga kerja melakukan migrasi ulang-alik sebesar 3,799\%. Hasil uji Z pada tingkat kesalahan $5 \%$ untuk jarak menunjukkan bahwa $\mathrm{z}$ hitung adalah sebesar 1,235 dan probabilitas z hitung sebesar 0,266 lebih besar dari $\alpha$ (o,05), sehingga Ho dapat terima. Hal ini berarti bahwa jarak secara parsial tidak berpengaruh secara signifikan terhadap keputusan tenaga kerja melakukan migrasi komutasi ulak-alik. Nilai konstanta sebesar $-4,926$. Artinya tanpa dipengaruhi beban taggungan keluarga, tingkat pendidikan, usia, status pernikahan, dan jarak nilai keputusan tenaga kerja melakukan migrasi ulang-alik adalah -4,9.

\section{Overall Fit Test}

Hasil pengujian omnibus tests of model coefficients diperoleh chi square sebesar 
38.954 dengan signifikansi sebesar o,ooo. Dengan nilai signifikansi yan lebih kecil dari 0,05 tersebut maka dapat disimpulkan bahwa keputusan melakukan migrasi ulangalik dapat diprediksi dari variabel beban tangguungan keluarga, tingkat pendidikan, usia, status pernikahan, dan jarak.

\section{Uji McFadden R2}

Dalam hal ini ada dua ukuran $\mathrm{R}$ square yaitu Cox \& Snell yaitu sebesar 0,323. Hal ini berarti bahwa dengan ukuran Cox \& Snell diperoleh hanya 32,3 \% variasi keputusan melakukan migrasi ulang-alik dapat diprediksikan dari beban tanggungan keluarga, tingkat pendidikan, usia, status pernikahan, dan jarak.

Dari hasil pengujian diperoleh nilai Chi Square sebesar 0,208 dengan nilai Sig sebesar 1,00o, sehingga terlihat bahwa nilai Sig lebih besar daripada alpha (0,05), yang berarti tidak ada perbedaan antara klasifikasi yang diprediksi dengan klasifikasi yang diamati. Itu berarti model regresi logistik telah cukup menjelaskan data dan bisa digunakan untuk analisis selanjutnya.

Dapat diketahui bahwa 98,9 persen yang memutuskan melakukan migrasi ulang-alik dapat diprediksi secara tepat oleh model regresi logistik ini. Sedangkan yang tidak dalam kategori melakukan migrasi ulang-alik dapat diprediksi secara tepat 62,5 persen.

\section{Rasio-Odd}

Nilai Odd Ratio variabel beban
tanggungan keluarga sebesar 9,277
bermakna kemungkinan setiap kenaikan
beban tanggungan keluarga, maka akan
menaikkan keputusan tenaga kerja
melakukan migrasi ulang-alik tenaga kerja
asal Kota Surakarta ke Kabupaten
Karanganyar sebesar 9,277 kali. Sedangakan

nilai Odd Ratio variabel tingkat pendidikan sebesar 5,829 bermakna kemungkinan keputusan tenaga kerja melakukan migrasi ulang-alik tenaga kerja asal Kota Surakarta ke Kabupaten Karanganyar dengan tenaga kerja yang tingkat Pendidikannya tinggi sebesar 5,829 kali dibandingkan dengan yang tingkat pendidikannya rendah.

Nilai Odd Ratio variabel usia sebesar 1,025 bermakna setiap usia tenaga kerja meningkat, maka akan menaikkan kemungkinan keputusan tenaga kerja melakukan migrasi ulang-alik tenaga kerja asal Kota Surakarta ke Kabupaten Karanganyar sebesar 1,025 kali. Sedangkan Nilai Odd Ratio variabel status pernikahan sebesar 44,662 bermakna kemungkinan keputusan tenaga kerja melakukan migrasi ulang-alik tenaga kerja asal Kota Surakarta ke Kabupaten Karanganyar dengan tenaga kerja yang sudah menikah sebesar 44,662 dibandingkan yang belum menikah atau lainnya.

Nilai Odd Ratio variabel jarak sebesar o,763 bermakna kemungkinan keputusan tenaga kerja melakukan migrasi ulang-alik tenaga kerja asal Kota Surakarta ke Kabupaten Karanganyar dengan tenaga kerja yang sudah jaraknya dekat sebesar o,763 dibandingkan yang jaraknya jauh.

\section{Hasil uji Pengaruh Variabel Beban Tanggungan Keluarga Terhadap keputusan Tenaga Kerja Melakukan Migrasi Ulang-Alik.}

Hasil analisis regresi logistic menunjukan bahwa variabel beban tanggungan keluarga memiliki nilai koefisien sebesar 2,228 dengan nilai signifikansi sebesar 0,036 yang lebih kecil dari $\alpha=5 \%$. Hal tersebut menunjukan variabel beban tanggungan keluarga berpengaruh secara 
signifikan terhadap keputusan tenaga kerja melakukan migrasi ulang-alik. Nilai odds rasio atau Exp (B) variabel pendapatan sebesar 9,277 yang berarti probabilitas responden yang memutuskan melakukan migrasi ulang-alik 9,277 kali lebih tinggi untuk responden yang memiliki beban tanggungan keluarga tinggi dibandingkan responden yang memiliki beban tanggungan rendah. Adapun tanda koefisien (+) menunjukan semakin tinggi beban tanggungan keluarga akan semakin besar probabilitas tenaga kerja untuk melakukan migrasi ulang-alik ke kabupaten karanganyar, begitu juga sebaliknya.

Hasil uji Tingkat Pengaruh Variabel Tingkat Pendidikan Terhadap keputusan Tenaga Kerja Melakukan Migrasi UlangAlik.

Hasil analisis regeresi logistic menunjukan bahwa variabel pendidikan memiliki nilai koefisien sebesar 1,763 dengan nilai signifikansi sebesar 0,051 yang lebih besarr dari $\alpha=5 \%$. Hal tersebut menunjukan variabel tingkat pendidikan tidak berpengaruh secara signifikan terhadap keputusan tenaga kerja melakukan migrasi ulang-alik. Adapun tanda koefisien (+) menunjukkan semakin tinggi tingkat pendidikan migran maka akan semakin besar probabilitas Hasil uji Pengaruh Variabel Usia Terhadap keputusan Tenaga Kerja Melakukan Migrasi Ulang-Alik

tenaga kerja untuk ke daerah tujuan sebagai migrasi ulang alik, begitu juga sebaliknya.

Hasil analisis regresi logistic menunjukan bahwa variabel umur memiliki nilai koefisien sebesar 0,025 dengan nilai signifikansi sebesar 0,0596 yang lebih besar dari $\alpha=5 \%$. Hal tersebut menunjukan variabel umur tidak berpengaruh secara signifikan terhadap keputusan tenaga kerja melakukan migrasi ulang-alik.

Hasil uji Pengaruh Variabel Status Pernikahan Terhadap keputusan Tenaga Kerja Melakukan Migrasi Ulang-Alik.

Hasil analisis regeresi logistic menunjukan bahwa variabel status pernikahan memiliki nilai koefisien sebesar 3,799 dengan nilai signifikansi sebesar 0,033 yang lebih kecil dari $\alpha=5 \%$. Hal tersebut menunjukan variabel status pernikahan berpengaruh secara signifikan terhadap keputusan tenaga kerja melakukan migrasi ulang-alik. Adapun tanda koefisien (+) menunjukkan orang dalam status menikah akan memiliki kecenderungan untuk melakukan migrasi ulang-alik. Nilai Exp (B) variabel umur sebesar 44,662 yang berarti probabilitas responden yang memutuskan melakukan migrasi ulang-alik 44,662 kali lebih tinggi untuk responden yang belum menikah atau lainnya dibandingkan responden yang sudah menikah.

\section{Hasil uji Pengaruh Variabel Jarak Terhadap keputusan Tenaga Kerja Melakukan Migrasi Ulang-Alik}

Hasil analisis regresi logistic menunjukan bahwa variabel jarak memiliki nilai koefisien sebesar -0,270 dengan nilai signifikansi sebesar 0,266 yang lebih besar dari $\alpha=5 \%$. Hal tersebut menunjukan variabel jarak tidak berpengaruh secara signifikan terhadap keputusan tenaga kerja melakukan migrasi ulang - alik.

\section{SIMPULAN}

Variabel beban tanggungan keluarga berpengaruh secara signifikan dan positif terhadap keputusan tenaga kerja melakukan migrasi ulang - alik dengan 
nilai signifikansi

sebesar

o,o14 yang lebih kecil dari $\alpha=5 \%$. Sebaliknya variabel tingkat pendidikan tidak berpengaruh secara signifikan dan positif terhadap keputusan tenaga kerja melakukan migrasi ulang-alik dengan nilai signifikansi sebesar 0,051 yang lebih besar dari $\alpha=5 \%$. Sedangkan variabel usia tidak berpengaruh secara signifikan dan positif terhadap keputusan tenaga kerja melakukan migrasi ulang alik dengan nilai signifikansi sebesar 0,0596 yang lebih besar dari $\alpha=5 \%$. Disisi lain variabel status pernikahan berpengaruh secara signifikan terhadap keputusan tenaga kerja melakukan migrasi ulang-alik dengan nilai signifikansi sebesar 0,033 yang lebih kecil dari $\alpha=5 \%$. Hal ini berbeda dengan variabel jarak yang memiliki pengaruh tidak signifikan dan positif terhadap keputusan tenaga kerja melakukan migrasi ulang alik dengan nilai signifikansi sebesar 0,226 yang lebih besar dari $\alpha=5 \%$.

\section{DAFTAR PUSTAKA}

Abidin, Zainal. (2013). Analisis Keputusan Tenaga Kerja Melakukan Migrasi Komutasi Di Kecamatan Wuluhan Kabupaten Jember. Skripsi. Jember: Fakultas Ekonomi Universitas Jember

Alamin, Rabul., Sidharta Adyatama dan Deasy Arisanty. "Faktor Yang Mempengaruhi Mobilitas Ulang-Alik Penduduk Kecamatan Tamban Menuju Kota Banjarmasin”. Dalam Jurnal Pendidikan Geografi Volume 2 Nomor 1 Januari 2015 Halaman 1-12 : Universitas Lambung Mangkurat.

Anggraini, Fitria Nur. (2016). Kesiapan Penggunaan Uang Elektronik Sebagai Fasilitas Penyaluran Dana Program Keluarga Harapan Dalam Rangka Financial Inclusion (Studi : Desa Genting, Kecamatan jambu, Kabupaten Semarang). Skripsi. Semarang: Fakultas Ekonomi Universitas Negeri Semarang
Anggraini, Hestu Rahma dan Fafurida. "Pengaruh Kondisi Individu Terhadap Keputusan Migrasi Sirkuler Ke Kota Semarang (Studi Pada Tenaga Kerja yang Bekerja di Kota Semarang)". Dalam Economics Analysis Journal 2016 Semarang:Universitas Negeri Semarang.

Rustariyuni, Surya Dewi. "Faktor-Faktor Yang Mempengaruhi Minat Migran Melakukan Mobilitas Non Permanen Ke Kota Denpasar". Dalam Piramida Volume IX Nomor 2 Desember 2013 Bali: Universitas Udayana.

Erlando, Angga. "Analisis Terhadap Migran Sirkuler Di Kota Surabaya”. Dalam Jurnal Ilmiah Universitas Brawijaya 2014 Malang:Universitas Brawijaya.

Ghozali, Imam dan Dwi Ratmono. 2013. Analisis Multivariat Dan Ekonometrika Teori, Konsep, Dan Aplikasi Eviews 8. Semarang:Universitas Diponegoro.

Hasyasya, Nisa dan Achma Hendra Setiawan. "Analisis Faktor-Faktor Yang Mempengaruhi Keputusan Tenaga Kerja Menjadi Commuter Dan Tidak Menjadi Commuter Ke Kota Semarang (Kasus Kabupaten Kendal)”. Dalam Diponegoro Journal Of Economics Volume 1 Nomor 1 Tahun 2012 Semarang: Universitas Diponegoro.

Ishaq, Dzulkarnaen., M. Saleh dan Fivien Muslihatiningsih. "Determinasi Migrasi Commuter Penduduk Kecamatan Bangsalsari Kabupaten Jember". Dalam Artikel Ilmiah Mahasiswa 2014 Jember: Universitas Jember.

Mujito, Anugrah P. "Analisis Faktor-Faktor Yang Mendorong Seseorang Untuk Melakukan Migrasi Ulang-Alik (Studi Kasus Pada Migran Kota Malang Yang Melakukan Migrasi Ulang Alik Ke Surabaya Dengan Menggunakan Transportasi Bus)”. Dalam Jurnal Ilmiah Universitas Brawijaya 2013Malang:Universitas Brawijaya.

Kusumaningrum, Syifa Putri. "Pengaruh Kondisi Individu Dan Sosial - Ekonomi Terhadap Keputusan Menjadi Commuter Ke Kota Jakarta

(Studi Pada Tenaga Kerja Sektor Formal Dari Bogor Dan Depok Yang Menggunakan Kereta Commuter Line)”. Dalam Jurnal Ilmiah Universitas Brawijaya 2014 Malang:Universitas Brawijaya.

Puspitasari, Ayu Wulan. (2010). Analisis faktor-Faktor yang mempengaruhi Minat Migrasi Sirkuler Ke Kabupaten Semarang. Skripsi. Semarang: Fakulltas Ekonomi Universitas Diponegoro 
Sari, Siska Puspita. (2016). Analisis Faktor-Faktor Yang Mempengaruhi Minat Migrasi Commuter Penduduk Kecamatan Silo Kabupaten Jember. Skripsi. Jember: Fakultas Ekonomi Universitas Jember

Shidiq, Ahmad dan Dyah Maya Nihayah. "FaktorFaktor Yang Mempengaruhi Keputusan Migrasi Commuter Di Kabupaten Demak”. Dalam Economics Development Analysis Journal 2016 Semarang: Universitas Negeri Semarang.

Susetyo Budi Hutomo. "Faktor-Faktor Yang Mempengaruhi Keputusan Melakukan Migrasi Ulang-Alik (Studi Kasus Tenaga Kerja Asal Kab. Semarang Ke Kota Semarang Dengan Menggunakan Transportasi BRT)". Dalam
Economics Development Analysis Journal 2015 Semarang:Universitas Negeri Semarang.

Syah, Sofyan. (2014). Pengaruh Pendapatan, Tingkat Pendidikan, Jenis Kelamin, Umur, dan Status Perkawinan Terhadap Keputusan Tenaga Kerja Kota Depok Menjadi Commuter Ke DKI Jakarta. Skripsi. Semarang: Fakultas Ekonomika dan Bisnis Universitas Diponegoro

http://jakartapedia.bpadjakarta.net/index.php/Migrasi http://panjinurrahmat.blogspot.co.id/2009/10/reviewbeberapa-teori-migrasi.html

www.bps.go.id

www.jateng.bps.go.id

Keputusan Gubernur Jawa Tengah Nomor 560/66 Tahun 2015

Kota Surakarta Dalam Angka 2016 